\title{
A snapshot of environmental iodine and selenium in La Pampa and San Juan provinces of Argentina
}

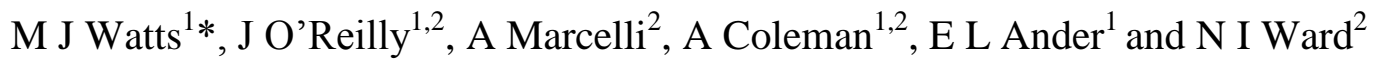 \\ 1. British Geological Survey, Keyworth, Nottingham, UK, mwatts@bgs.ac.uk Tel: +44 (0)115 \\ 9363042, Fax: +44 (0)1159363329 \\ 2. Chemical Sciences, FHMS, University of Surrey, Guildford, UK. n.ward@ surrey.ac.uk
}

\section{Abstract}

Soil and water samples were collected from farmsteads and provincial towns across the provinces of La Pampa and San Juan in Argentina. Inductively coupled plasma mass spectrometry was used for the determination of iodine in water following addition of tetramethyl ammonium hydroxide (TMAH) to $1 \% \mathrm{v} / \mathrm{v}$ and soils extracted with 5\% TMAH. Iodine in agricultural soils was in the range of $1.3-20.9 \mathrm{mg} / \mathrm{kg}$ in La Pampa located in central Argentina and $0.1-10.5 \mathrm{mg} / \mathrm{kg}$ in San Juan located in the northwest Andean region of Argentina, compared to a worldwide mean of $2.6 \mathrm{mg} / \mathrm{kg}$ for soils $>50 \mathrm{~km}$ from the coast. Mean selenium concentrations for soils from both provinces were $0.3 \mathrm{mg} / \mathrm{kg}$, compared to a worldwide mean of $0.4 \mathrm{mg} / \mathrm{kg}$. The majority of soils were alkaline, although ranged from $\mathrm{pH}$ 6.7 to 8.8. The soil organic matter content of soils in La Pampa was $2.5-5.9 \%$ and in San Juan $0.1-2.3 \%$, whilst, mobile water extractable soil iodine was 1 - $18 \%$ for La Pampa and 2 - $42 \%$ for San Juan. No simple relationship observed for $\mathrm{pH}$ and organic content, but mobile iodine (\%) was highest when organic content was low, higher for lower total iodine concentrations and generally highest at $\mathrm{pH}>7.5$. Water drawn for drinking or irrigation of a variety of crops and pasture was found to range from 52 to $395 \mu \mathrm{g} / \mathrm{L}$ iodine and 0.8 to 21.3 $\mu \mathrm{g} / \mathrm{L}$ selenium in La Pampa and $16-95 \mu \mathrm{g} / \mathrm{L}$ iodine and 0.6 to $8.2 \mu \mathrm{g} / \mathrm{L}$ selenium in San Juan. The water samples were alkaline between $\mathrm{pH} 8$ and 10. Water-iodine concentrations were highest at $\mathrm{pH} 7.8$ to 8.8 and in groundwaters positively correlated with conductivity. Raw water entering a water treatment works in La Pampa was reduced in iodine content from approximately $50 \mu \mathrm{g} / \mathrm{L}$ in raw water to $1 \mu \mathrm{g} / \mathrm{L}$ in treated drinking water, similar to levels observed in regions experiencing iodine deficiency.

Keywords

Goitre, Iodine deficiency, ICP-MS

\section{Introduction}

Approximately 1.9 billion people worldwide were estimated to be at risk of iodine deficiency disorders (IDD) (Benoist et al., 2003). A daily intake of $150 \mu \mathrm{g}$ of iodine per adult is recommended to prevent IDD (Delange, 1993; WHO, 2004). Below $100 \mu \mathrm{g} / \mathrm{day}$, a series of thyroid functional and developmental abnormalities occur (Hetzel, 1989. Dunn, 1998), in which symptoms can occur as goitre, hypothyroidism, or impaired mental function in adults. In the fetus, neonates and children IDD can lead to lower levels of thyroid hormones necessary for normal brain development, leading to irreversible brain damage and possible IQ that is 10 to 15 points lower than sufficient iodine intake (ICCIDD, 2009). In addition, physical development can be effected as a result of a range of associated disorders including still birth, congenital anomalies, endemic cretinism or short stature. UNICEF, ICCIDD and WHO reported detailed recommendations for the daily intake of iodine; $90 \mu \mathrm{g}$ for 0 to 5 year old children, $120 \mu \mathrm{g}$ for 6 to 12 year old children, $150 \mu \mathrm{g}$ for adolescents and adults, $250 \mu \mathrm{g}$ for 
pregnant and lactating women (WHO, 2007a). Four methods are commonly used for the monitoring of iodine nutritional status in populations and summarised as: (1) measurement of goitre by the physical inspection of the neck, palpation or thyroid ultrasonagraphy reflects long-term iodine intake (months-years), (2) measurement of urinary iodine (UI) concentrations since $90 \%$ or more of ingested iodine is excreted in the urine and provides an indication of recent iodine intake (days), (3) measurement of Thyroid Stimulating Hormone (TSH) in serum, which is elevated when iodine supply is low, particularly in infants, and (4) Thyroglobulin (Tg) in serum which increases due to greater thyroid mass or TSH stimulation and provides an intermediate response (weeks-months). Tg correlates well with UI indications of deficiency and can be simply assayed on dried blood spots. This method also provides a good indication of improved thyroid function after iodine repletion. A more detailed appraisal of these monitoring techniques is described by Zimmerman (2008).

Despite concerted efforts to alleviate IDD in the twentieth century, the incidence of IDD increased by $32 \%$ between 1993 and 2003 afflicting some 2 billion people (WHO, 2004). Moderate to severe endemic goitre due to iodine deficiency has been historically reported in Argentina. Provinces in the north and west of the country, particularly in the Andean foothills have been affected, in particular La Pampa and San Juan, the focus of this study. In Argentina, $90 \%$ of the population was estimated to receive iodized salt (WHO 2004, ICCIDD, 2003), as a result of a programme of supplementation since the 1950/60s and resulted in a significant decrease in goitre prevalence in many areas. A relapse of goitre in some regions experiencing goitre rates of 10 to $42 \%$ in the 1980 s and 1990s. The main reasons for this relapse were poor understanding of the problem, inadequate support for education, enforcement, monitoring, quality control of salt iodisation and poor coordination of agencies involved (ICCIDD, 2009). The World Health Organisation (2007b), estimated the a prevalence of goitre in newborns in Buenos Aires to be $83 \%$ and across provincial states ranging from rates of 4 to $19 \%$ for 5 to 16 year olds according to goitre prevalence and urinary iodine measurements. Goitre prevalence was reported in a study group of school children at rates of 9, 10 and $12 \%$, in San Juan (capital of San Juan province), Punta del Medano (rural) and Colonia Fiscal (rural), respectively. In addition, goitre prevalence was reported to be $11 \%$ in Santa Rosa the capital of La Pampa and $18 \%$ in Altaliva Roca (rural) amongst school children (ICCIDD, 2003). In countries where goitre rates are above $10 \%$ of the population, iodine deficiency is often estimated to be widespread and can have the effect of reducing the national IQ by 10 to $15 \%$ (Stewart et al., 2003). In a separate study, Morando et al. (2004) stated that although the goitre rates in San Juan province had previously been reported to have been reduced from 30 to $16 \%$ since the introduction of salt iodisation, they had determined that palpable enlarged thyroids or Grade 1 goitre (Lewinski, 2002; WHO, 1994) were present in $10 \%$ of children studied in the towns of Punta del Medano and Colonia Fiscal. Morando et al (2004) suggested that the rates of goitre were not due to the ingestion of goitrogenic foods, but likely probable presence of goitrogenic substances in well water or possible gaps in the supplementation of iodine in the diet. Cebrian et al. (1993) reported in a comparative study of patients from areas with known high and low arsenic levels in drinking water that reduced absorption rates of iodine by the thyroid gland occurred in individuals with chronic arsenicosis. Arsenic concentrations in Argentinian surface and groundwaters have been reported at well above World Health Organisation recommended limits of $10 \mu \mathrm{g} / \mathrm{L}$ As (WHO, 1993; Smedley et al., 2002, 2005; O’Reilly et al., 2007).

Selenium deficiency may be an important factor in the onset of IDD through the inhibition of thyroid hormone metabolism. Selenoenzyme, type 1 iodothyronine deiodinase influences the production of thyroid hormones, ultimately controlling cellular development, particularly in the 
foetus and early infancy (Arthur et al., 1999). A recommended daily intake of 55 to $75 \mu \mathrm{g}$ per day is recommended to prevent selenium deficiency (WHO, 1996).

Environmental samples are often used by geochemists to estimate the exposure or prevalence of iodine status in a population or region. Soils generally contain $0.01-6 \mathrm{mg} / \mathrm{kg}$ iodine and in some coastal areas up to $80 \mathrm{mg} / \mathrm{kg}$ (Kebata-Pendias, 1984). The weathering of rocks generally contributes little to the soil iodine pool, other than via the important mechanism of governing the physico-chemical properties of the soil formed. Factors that determine the concentration of iodine in soils are the proximity to coast, soil $\mathrm{pH}$, soil organic content and the presence of iron and aluminium oxides in the soil (Fuge, 2005). The majority of iodine found in soils is ultimately derived from the sea and transported through rainfall as $\mathrm{CH}_{3} \mathrm{I}$ (for long-range transport), HI or $\mathrm{I}_{2}$ (Fuge, 2005). The semi-arid region of San Juan in the Argentinian Andes receives on average 100 to $200 \mathrm{~mm}$ of rainfall per year and relies on melt water from the Andes (Cabido et al., 1993), compared to La Pampa at approximately $700 \mathrm{~mm}$ per year, which falls sporadically mainly in the North East of the province (www.accessmylibrary.com), where water supplies are dependent on boreholes. Whilst San Juan is situated closer to the coast than La Pampa, the Andean mountain range creates a rain shadow over San Juan. Precipitation at altitude can result in the washout of iodine from the atmosphere in regions such as the Andes (Dunn and Van de Haar, 1990) on the Chilean / Pacific coastal side of the Andes, where excessive iodine intake has been reported (ICCIDD, 2009), leaving reduced deposition of iodine through precipitation on the Argentinian side of the Andes. The potential for iodine to become adsorbed by soil components is influenced by some complex factors, including: organic content, often low in mountainous regions due to erosion and closely correlates with the retention of iodine in soils (Watts and Mitchell, 2009, Johnson 2002); the geochemistry relating to the presence of $\mathrm{Fe}$ and $\mathrm{Al}$ oxides (Fuge, 2005) and the $\mathrm{pH}$ of the soil. The sorption of iodide by $\mathrm{Fe}$ and $\mathrm{Al}$ oxides is greatest under acidic conditions (Fuge, 2005). The majority of soils reported in the literature contain less than $10 \%$ water-soluble iodine, although this may be expected to increase in arid alkaline soils (Fuge, 2005), such as those found in the Argentinian Andes.

The selenium content of the majority of soils is in the range of 0.1 to $2 \mathrm{mg} / \mathrm{kg}$ (Kebata-Pendias, 1984), with a world mean of $0.4 \mathrm{mg} / \mathrm{kg}$, but high concentrations of up to $1200 \mathrm{mg} / \mathrm{kg}$ have been reported in seleniferous regions (Fordyce 2005). Whilst the total selenium concentrations in soils provide a general overview of environmental status, it is the mobility of selenium rather than the underlying geology that mostly influences the uptake into plants and animals. Selenite is the most stable form, which is more readily adsorbed onto soil particles than selenate. This process is $\mathrm{pH}$ dependent, in acidic soils, selenite forms insoluble oxyhydroxide complexes, resulting in selenite being less mobile. Selenate is the most common chemical form in alkaline soils and is generally more mobile and available for uptake by plants (Fordyce 2005).

The Pacific coastal side of the Chilean Andes has been reported to be iodine excessive based on public health studies (WHO, 2004), whilst the global distribution of IDD as illustrated by Dunn \& Van der Haar (1990) illustrated the prevalence of IDD occurring across central South America, in mountainous and rain shadow regions, particularly on the Argentinian side of the Andes. Whilst there have been many reports on the iodine status of the Argentinian population through epidemiological studies, this study provides a limited snapshot of the iodine and selenium status of agricultural soils and irrigation and drinking water in the semi-arid Andean western province of San Juan and lower steppe province of La Pampa in central Argentina. This data will contribute to the understanding of the stubborn prevalence of goitre in parts of 
Argentina and fill in some gaps in the knowledge of environmental levels of iodine and selenium. The samples were analysed using an inductively coupled plasma mass spectrometer (ICP-MS) for fast and sensitive analyses. For iodine determination, iodine was extracted from soils using an alkaline extraction, whilst waters were spiked with the same alkaline reagent (Watts 2001, Johnson et al. 2002, Watts and Mitchell 2009). Selenium measurements were completed following acidification of the waters and total acid digestion of the soils.

\section{Study Sites}

The location of towns and rivers sampled for soil and water are illustrated in Figure $1 \mathrm{~b} \& \mathrm{c}$. The study sites in the province of San Juan are located approximately 250 to $380 \mathrm{~km}$ from the Pacific coast, with an elevation ranging from $1600 \mathrm{~m}$ from cuesto del viento in the west to Encon at $500 \mathrm{~m}$ in the east. Study sites were located in the north of La Pampa at an elevation of $200 \mathrm{~m}$, located approximately $450 \mathrm{~km}$ from the Atlantic coast. Soils were collected from cultivated fields or small vegetable plots, and water was collected from rivers or wells that supplied drinking water for human consumption. The same water supply was often used for animals and the irrigation of cultivated plots. The sites were selected based on their direct interaction with the source-pathway-receptor, via crop production, grazing and drinking water. Details of the sites are as follows:

1. San Juan: Thirteen soils and twenty one water samples were collected from each of the following sites: (1) Rio Blanco - Angualusta (ANG), Cuesto del Viento (CU); (2) Rio Jachal (RJ) - Agua Negra (AN); (3) Rio Huaco - Huaco (HU); and (4) Encon (EN) in the south of the province. All waters were stream or river fed, with the exception of Encon where boreholes were used for water supplies. The soils along the Rio Blanco, Jachal, Huaco and the village of Encon were underlain by continental marine sediments (DNGM, 1964).

2. La Pampa: Fifteen soils and fifteen water samples were collected from farmsteads around the towns of Ingeniero Luigi (LU) and Eduardo Castex (EC). Groundwater samples from these towns were also collected from the respective town boreholes and water treatment plants. Soils from Ingeniero Luigi and Eduardo Castex are underlain by loess up to $200 \mathrm{~m}$ in depth, with a thin layer of ash below the surface (DNGM, 1964, Smedley et al., 2005). Volcanic activity has had an important impact on the formation of Pampean loess from the Tertiary and Quaternary periods through to the present day. The last major ash fall was in 2000 from the Copahue volcano (Ibanez et al. 2008) and in 1932 Quiza Pu volcano (Zarate et al. 1989). The presence of a fine layer of rhyolitic ash in the upper part of the loess soil profile is believed to be derived from the Quiza Pu eruption of 1932 (Smedley et al. 2002).

\section{Materials and methods}

Water samples $(30 \mathrm{ml})$ were collected and filtered on-site using a $0.45 \mu \mathrm{m}$ syringe filter. In addition, a composite sample of $0.5 \mathrm{~kg}$ of soil was collected with a spade from the top $20 \mathrm{~cm}$ layer of soil. Samples were dried in a drying oven at $40^{\circ} \mathrm{C}$ overnight, disaggregated and sieved using a nylon mesh to $<2 \mathrm{~mm}$ and then sieved to $<125 \mu \mathrm{m}$. Loss on ignition (LOI) was used as an indication of organic matter content in these mainly sandy soils. The LOI of the soils was determined on $1 \mathrm{~g}$ (dry weight) of soil and recorded as a percentage of weight. Soil $\mathrm{pH}$ was determined on a $10 \mathrm{~g}$ (dry weight) soil sample to which $10 \mathrm{ml}$ of $0.01 \mathrm{M} \mathrm{CaCl}_{2}$ solution had been added. The $\mathrm{pH}$ of the soil paste was measured with a standard Orion $\mathrm{pH}$ meter. This method generally gives a lower soil $\mathrm{pH}$ determination $(0.5 \mathrm{U})$ than water-based methods (Taylor et al. 2005).

Iodine determination 
The methodology for the measurement of iodine in water and soil is based on the work of Watts and Mitchell (2009). Water samples were spiked with $25 \%$ tetramethyl ammonium hydroxide (TMAH: Sigma Aldrich, Kent, UK) to result in a final solution of $1 \%$ TMAH. For soils, $0.25 \mathrm{~g}$ (dry weight) of sample was weighed directly into a $15 \mathrm{ml}$ poly(tetrafluoroethene) bottle to which $5 \mathrm{ml}$ of $5 \%$ TMAH was added and shaken. Sample bottles, with lids loosened, were placed in a drying oven at $70^{\circ} \mathrm{C}$ for 3 hours, with bottles shaken at 1.5 hours. After 3 hours of heating, $5 \mathrm{ml}$ of deionised water was added and the bottles centrifuged at $2500 \mathrm{rpm}$ for 20 minutes. The supernatant was removed from the top of the sample solution and diluted to a final matrix of $1 \%$ TMAH. Soluble iodine was determined by cold water extraction, with $12.5 \mathrm{ml}$ of deionised water and $1.25 \mathrm{~g}$ of soil shaken for 15 minutes, centrifuged at 2,500 rpm for 10 minutes and adjusted to a matrix of $1 \%$ TMAH for analysis. Soil preparations for selenium determinations were completed through acid digestion as described by Watts et al. (2008). Final solutions were acidified to $1 \% \mathrm{HNO}_{3}$ for selenium determinations. Iodine and selenium were determined in separate analytical runs, owing to the incompatibility of the two matrices. All sample solutions were analysed by an Agilent 7500 ICP-MS instrument (Agilent, Hemel Hempstead, UK). An internal standard of $100 \mu \mathrm{g} / \mathrm{L}$ rhenium in $1 \%$ TMAH was mixed with the sample solution via a t-piece for iodine or $50 \mu \mathrm{g} / \mathrm{L}$ tellurium in $1 \% \mathrm{HNO}_{3}$ for selenium measurements to correct for signal drift during the analytical run $(<1 \%$ signal change in internal standard). Iodine determinations were completed in standard mode as described in Watts and Mitchell (2009) and selenium in collision cell mode, using $\mathrm{He}$ as a buffer gas as described in Watts et al. (2008). Water certified reference materials NASS-4, IAPSO, SLRS-2 (iodine) and NIST SRM 1643e (selenium) were employed for quality control checks throughout the analytical runs. The accuracy and precision of the method for measuring iodine was evaluated and reported in Watts and Mitchell (2009) using a selection of appropriate soil certified reference materials (CRM). The accuracy of iodine measurements in soil certified reference materials, were within $15 \%$ of target values, as were selenium measurements for NIST SRM 2711 for selenium measurements.

\section{Results and discussion}

Mean water-iodine concentrations (Table 1) show a substantial difference between the river waters of San Juan and the groundwaters of La Pampa, as summarised by Figure 2 with mean concentrations of $40 \mu \mathrm{g} / \mathrm{L}$ (median of $30 \mu \mathrm{g} / \mathrm{L}$ ) in San Juan and $145 \mu \mathrm{g} / \mathrm{L}$ (median of $110 \mu \mathrm{g} / \mathrm{L}$ ) in La Pampa. The river waters from the area of San Juan had concentrations which were much higher than other mountainous regions, such as the Himalayas $(<1.0 \mu \mathrm{g} / \mathrm{L})$ with similar topography to San Juan, where goitre has been reported (Day and Powell-Jackson, 1972) or mountainous Afghanistan at 5 to $23 \mu \mathrm{g} / \mathrm{L}$ (Watts and Mitchell, 2009), and are high compared to many river waters cited in the literature (Fuge, 1989). The groundwaters from the loess of La Pampa had iodine concentrations with a lower range than those found by Smedley et al. (2005) (median of $229 \mu \mathrm{g} / \mathrm{L}$, mean $243 \mu \mathrm{g} / \mathrm{L}$ ). However, these two datasets are broadly comparable when taken in the context of the range of groundwater concentrations shown in the literature. The exceptions to this are high (mean $>300 \mu \mathrm{g} / \mathrm{L}$ ) concentrations from similar plain settings in parts of China (Zhao et al., 1998), or where higher iodine concentrations from brines or thermal waters are implicated (Fuge \& Johnson, 1986). The high conductivity values observed in most La Pampa waters compared to San Juan are also characterised by generally lower $\mathrm{pH}$ values (Table 1). A positive correlation between conductivity and iodine concentration was observed (Figure 3), with a Pearson correlation coefficient of $0.5(\mathrm{P}<0.002)$. This relationship is controlled by the variable and highly evolved Pampean groundwaters, where the high conductivity reflects the high total dissolved solids. Whilst no simple relationship between aqueous iodine concentrations and $\mathrm{pH}$ can be observed, comparison of 
data in Table 1 with that of Smedley et al. (2005) for La Pampa, shows that all iodine concentrations $>200 \mu \mathrm{g} / \mathrm{L}$ occur in the $\mathrm{pH}$ range $7.8-8.8$. A water treatment plant in Ingeniero Luiggi was set up to remove the high levels of arsenic in groundwater supplies to the town by precipitation with iron hydroxide and reverse osmosis. It would appear that the treatment plant also reduces the iodine content from approximately $50 \mu \mathrm{g} / \mathrm{L}$ in the raw water (LU39a) from supply wells to $1 \mu \mathrm{g} / \mathrm{L}$ in the treated drinking water (LU39g), resulting in similar levels to IDD prone areas, whilst the waste water (precipitate) contained elevated levels of iodine at $87 \mu \mathrm{g} / \mathrm{L}$. Selenium concentrations were also reduced from approximately 3 to $<0.5 \mu \mathrm{g} / \mathrm{L}$, comparable to that for waters in selenium deficient regions (Fordyce et al., 2002). An increase in selenium concentration was measured in the waste water at $4.7 \mu \mathrm{g} / \mathrm{L}$.

Soil concentrations and physico-chemical parameters are given in Table 2, with soil-iodine ranges of $0.05-10.5 \mathrm{mg} / \mathrm{kg}$ in San Juan and 1.2 - $20.9 \mathrm{mg} / \mathrm{kg}$ in La Pampa. However, there are four datapoints, which may represent very localised positive anomalies, rather than being representative of wider soil conditions. The high soil-iodine value for AN01, is thought to arise from proximity to a stream and flooding from iodine-rich waters (Table 1). In addition, soils collected from EC2 S5, EC7 S2 and EC8 S2 were relatively high in iodine (>4 mg/ $\mathrm{kg}$ ) and in close proximity to water tanks used to store iodine rich groundwater. Otherwise similar soils, collected within 10 to 20 metres of the elevated soil-iodine sites (EC2 S2, EC7 S1, EC8 S1), were generally low $(<2.6 \mathrm{mg} / \mathrm{kg})$, suggesting that leakage from the storage tanks may have resulted in a localised elevation of soil-iodine. When these outliers are excluded the summary values for San Juan are a mean of $1.1 \mathrm{mg} / \mathrm{kg}$ (median of $0.35 \mathrm{mg} / \mathrm{kg}$ ), and a mean of $2.3 \mathrm{mg} / \mathrm{kg}$ (median of $2.2 \mathrm{mg} / \mathrm{kg}$ ) in La Pampa, with a systematic variation between those two areas, which mimics that of the aqueous iodine concentrations (Figure 4). The majority of soils from La Pampa were close to the worldwide geometric mean of $2.6 \mathrm{mg} / \mathrm{kg}$, for inland regions further than $50 \mathrm{~km}$ from the coast (Johnson, 2003a), whilst those from San Juan were much lower (Figure 4). Goitre has been reported as prevalent where soils contained mean soil-iodine of 5.4 $\mathrm{mg} / \mathrm{kg}$ in the UK (Fuge, 1989), $3.1 \mathrm{mg} / \mathrm{kg}$ in Sri Lanka (Fordyce et al., 2000), $1.0 \mathrm{mg} / \mathrm{kg}$ in China (Fordyce et al., 2003), $2.1 \mathrm{mg} / \mathrm{kg}$ in Morocco (Johnson et al., 2002) and $2.4 \mathrm{mg} / \mathrm{kg}$ in Afghanistan (Kabul) (Watts and Mitchell, 2009). Whilst these studies were specific surveys rather than representative of countrywide iodine status, they are useful when trying to gauge the soil-iodine statusfor San Juan and La Pampa, which could be considered to be of poor iodine status, when compared to those values.

Water extractable soil-iodine was 2 to $42 \%$ (mean 19\%) of total iodine in San Juan soils, with five of the thirteen soils above $20 \%$ mobile iodine (Table 2). Soils from La Pampa exhibited 1 to $18 \%$ (mean $6 \%$ ) mobile iodine, with the majority of soils $<5 \%$ and just two soils above 10 $\%$. There is little comparable data on mobile iodine, although Johnson et al. (2002) reported extractable soil-iodine, using the same method, in Morocco at between 2 to $10 \%$ where bioavailable iodine was considered to be low. The percentage values for San Juan mobile iodine are relatively high compared to the Moroccan data and provide a valuable indication of the bioavailable iodine. However, these values should be taken in context with the actual concentrations of mobile iodine, which are in many cases extremely low $(<0.1 \mathrm{mg} / \mathrm{kg})$. The range of mobile iodine concentrations is very similar despite the difference in percentage values, San Juan 0.01 to $0.93 \mathrm{mg} / \mathrm{kg}$ (mean $0.20 \mathrm{mg} / \mathrm{kg}$ ) and La Pampa 0.04 to $0.94 \mathrm{mg} / \mathrm{kg}$ (mean $0.20 \mathrm{mg} / \mathrm{kg}$ ) (Figure 5).

Whilst increasing mobile iodine (mass) corresponds to increasing total iodine, there is no such relationship with the available mass and percentage iodine data. Soil $\mathrm{pH}$ and loss-on-ignition (as a measure of organic carbon) vary systematically between the two regions (Table 2), with generally higher $\mathrm{pHs}$ in San Juan (mean of 7.8) compared to La Pampa (mean of 7.2), whilst 
the latter has higher organic carbon (loss-on-ignition mean of $3.8 \%$ ) than San Juan (mean of $1.0 \%$ ). The slightly alkaline $\mathrm{pH}$ is likely to have contributed to the low iodine values through poor absorption onto $\mathrm{Fe}$ and $\mathrm{Al}$ oxyhydroxides and clay minerals. The organic matter content of soils in both areas are low compared to organic rich soils in the UK where total soil iodine is correspondingly higher (Fuge 2005; Watts and Mitchell, 2009). In this study, there is no simple relationship between loss-on-ignition and total iodine, although for the lowest concentrations in both (LOI $<4 \%$ and $\mathrm{I}<3 \mathrm{mg} / \mathrm{kg}$ ) there is a positive linear relationship. An inverse relationship between organic matter and mobile iodine $(\%)$ can be seen in Figure 6 , the correlation of $-0.600\left(\mathrm{R}^{2}\right)$ for both provinces was observed at a probability level of 0.05 $(\mathrm{P}<0.01)$. The majority of organic rich soils probably have a mobile iodine content of less than $10 \%$ of the total, although arid alkaline soils are likely to contain elevated levels of mobile iodine (Fuge, 2005) as is seen for San Juan. No simple relationship was observed between soil $\mathrm{pH}$ and the three measures of iodine. However, in these data the higher $(>10 \%)$ mobile iodine falls only in those samples where $\mathrm{pH}>7.8$, which are also the samples with the lowest loss-onignition values (Figure 6), suggesting multi-factorial controls on iodine concentrations and mobility.

There is no accepted threshold figure in the literature for defining an iodine deficient environment, or what sample media that measurement should be made in. The comparison of data from a range of studies is often the most appropriate approach, encompassing a combined approach to determining medical and environmental parameters in order to provide remediation strategies. However, it is common that such parameters are defined separately and compared against IDD regions reported in the literature. Soils in San Juan (mean $1.1 \mathrm{mg} / \mathrm{kg}$ ) and La Pampa (mean $2.3 \mathrm{mg} / \mathrm{kg}$ ) can be considered as an iodine poor environment since the concentrations are below reported values in regions afflicted by IDD. This is not the case with the aqueous iodine concentrations in either region. San Juan, where the median value is $39 \mu \mathrm{g} / \mathrm{L}$ exceeds most data in comparison to other studies of aqueous iodine (Fuge, 1989), including those where symptoms of IDD are not recognised. Concentrations of iodine in the more highly evolved groundwaters of the Pampean Plain are very high in relation to literature values from outside this region (Fuge, 1989) but, unless appropriately treated, these waters are widely recognised to contain arsenic and other potentially hazardous trace elements at concentrations which may be detrimental to health (Smedley et al., 2005; O'Reilly et al., 2007).

Mean water-selenium concentrations were $1.8 \mu \mathrm{g} / \mathrm{L}$ in San Juan, generally low compared to 2 to $19 \mu \mathrm{g} / \mathrm{L}$ reported by Fordyce (2005) for Argentinian surface waters. A mean waterselenium concentration of $6.4 \mu \mathrm{g} / \mathrm{L}$ in La Pampa, follows the pattern for higher groundwater concentrations compared to surface water reported by Hem (1992), due to greater contact time for rock-water interactions. The majority of water samples (Table 1) were significantly higher than selenium deficient waters reported by Fordyce et al. (2000) in Sri Lanka and China (2003) at less than $0.1 \mu \mathrm{g} / \mathrm{L}$. Mean soil-selenium concentrations (Figure 2) of $0.3 \mathrm{mg} / \mathrm{kg}$ in San Juan and $0.3 \mathrm{mg} / \mathrm{kg}$ in La Pampa were marginally lower than the worldwide mean of $0.4 \mathrm{mg} / \mathrm{kg}$ (Fordyce, 2005) and soils reported by Fordyce et al. (2000) for Sri Lanka at 0.1 to $5.2 \mathrm{mg} / \mathrm{kg}$. Argentinian soils in this study are generally greater in selenium content than reported threshold values of $<0.125 \mathrm{mg} / \mathrm{kg}$ for deficient soils and $<0.125$ to $0.175 \mathrm{mg} / \mathrm{kg}$ for marginally deficient soils (Fordyce et al., 2003), with the exception of just three samples. Although, total soilselenium values of 0.1 to $0.6 \mathrm{mg} / \mathrm{kg}$ have been considered deficient, since these concentrations have been reported in soils where selenium deficiency has been prevalent in livestock (Fordyce, 2005). No relationship of total selenium with either $\mathrm{pH}$ or soil organic matter was observed for data in this study. 


\section{Conclusion}

Argentinian environmental samples were largely considered to be selenium sufficient, through comparison with reported studies from other parts of the world. Water-iodine concentrations were greater than literature values for IDD areas. The highest concentrations were measured in $\mathrm{pH} 7.8$ to 8.8 and in groundwaters positively correlated with conductivity, also demonstrated by Smedley et al. (2005). However, many of the soils were consistent with iodine deficient areas at $<3.1 \mathrm{mg} / \mathrm{kg}$ (Fordyce et al., 2003). Stewart et al. (2003) raised concerns over the direct correlation of total soil-iodine to the prevalence of IDD. Rather there is a need to understand the bioavailable fraction in order to better understand the factors that influence IDD. No simple relationship occurred between total iodine or selenium with $\mathrm{pH}$ and soil organic matter content. Soluble (mobile) soil-iodine was elevated in San Juan soils (mean 19 $\%)$ in comparison to La Pampa (6\%), likely due to the slight differences in organic matter of 1.0 and $3.8 \%$ (mean LOI), respectively. Mobility as a percentage of the total iodine was highest when soil organic matter were low, higher for lower total iodine concentrations and generally highest when the $\mathrm{pH}$ was greater than 7.5. Soils are influential in the nutritional status of humans and animals. Geochemical mapping can stimulate investigations into the cause of diseases and aid the planning of public health corrective responses (Abrahams, 2006). Mitigation strategies, such as the common practice of salt iodisation in Argentina or direct supplementation are often patchy (Morando et al., 2004). Localised mitigation strategies have been proposed for the improvement of soil-iodine, such as crop biofortification (Xiao-E et al., 2007), addition of Chilean iodine rich nitrate fertilisers, soil improvement through addition of organic matter (Aston and Brazier, 1979; Johnson 2003b) or iodination of well water or irrigation water (Maberley et al., 1981; Elnager et al., 1997; Lim, et al. 2006). The influence of iodine rich irrigation water was observed in soils sampled close to iodine rich rivers subject to spring flooding in San Juan or in close proximity to groundwater storage tanks in La Pampa. Whilst the majority of waters contained elevated levels of iodine, careful attention should be given to population status resulting from raw water treated for arsenic removal that was iodine sufficient, such as in Ingeniero Luiggi where concentrations of $<5 \mu \mathrm{g} / \mathrm{L}$ iodine in treated drinking water is consistent with IDD prone areas. The high iodine content of San Juan waters and high mobility of what are low soil iodine concentrations are also worthy of further study, particularly when considering the prevalence of goitre in San Juan province reported by Morando et al. (2004).

\section{Acknowledgements}

The author wishes to thank Mr Adrian Brizio (Cospec, Eduardo Castex) and Mr Adrian Fenocchio (Copeospil Ltda, Ingeniero Luiggi) for assistance in the collection of water samples in La Pampa. Thanks are extended to Dr Chris Johnson of the BGS for checking the manuscript and Mr Paul Lappage for the preparation of the maps. This work is published with the permission of the Director of the British Geological Survey. 


\section{References}

Abrahams, P.W. (2006). Soil geography and human disease: A critical review of the importance of medical cartography, Progress in Physical Geography, 30, 490 - 512.

Arthur, J.R. and Beckett, G.T. (1994). New metabolic roles for selenium, Procedural Nutritional Society, 53, $615-624$.

Aston, S.R. and Brazier, P.H. (1979). Endemic goitre, the factors controlling iodine deficiency in soils, Science of Total Environment, 11, 99 - 104.

Benoist, B., Andersson, M. Takkouche, B. and Egli, I. (2003). Prevalence of iodine deficiency worldwide, Lancet, 362, 1859 - 1860.

Cabido, M., Gonzalez, C., Acosta, A. and Diaz, S. (1993). Vegetation changes along a precipitation gradient in Central Argentina, Vegetation, 109, 5 - 14.

Cebrian, M., Albores, A., Camara, V, Gonzalez, D., Gotelli, C., Hopenhayn, C., Kosatsky, T., Romieu, I. and Vega, F. (1993). Chapter 4, Heavy metals: In Environmental Epidemiology: A project for latin America and the Caribbean, Ed. Finkelman, J., Corey, G. and Calderon, R., pp $97-119$.

Day, T.K. and Powell-Jackson, P.R. (1972). Fluoride, water hardness and endemic goitre, Lancet, 1, $1135-1138$.

Delange, F. (1993). The disorders induced by iodine deficiency. Thyroid, 4, $107-128$.

DNGM (Direccion Nacional de Geologia y Mineria). (1964). Map geologica de la Republica Argentina, H8740 majari (1), ISBN X780636456.

Dunn, J.T. and Van der Haar, F. (1990). A Practical guide to the correction of iodine deficiency, International Council for the Control of Iodine Deficiency Disorders Technical Manual No. 3.

Dunn, J.T., (1998). Editorial: What's happening to our Iodine? Journal of Clinical Endocrinology and Metabolism, 83 (10), 3398 - 3400.

Elnager, B., Eltom, M., Karlsson, F.A., Bourdoux, P.P. and Gebremedhin, M. (1997). Control of iodine deficiency using iodination of water in a goitre endemic area, International Journal of food Sciences and Nutrition, 48, $119-127$.

Fordyce, F.M., Johnson, C.C., Navarante, U.R.B., Appleton, J.D. and Dissanayake, C.B. (2000). Selenium and iodine in soil, rice and drinking water in relation to endemic goitre in Sri Lanka. Science of Total Environment, 263, 127 - 141.

Fordyce, F.M., Stewart. A.G., Ge, X., Jiang, J.-Y and Cave, M. (2003). Environmental controls in IDD: A case study in the Xinjiang province of China, British Geological Survey Technical Report CR/01/045N. 
Fordyce, F.M. (2005). Chapter 15 Selenium deficiency and toxicity in the environment In: Essentials of Medical Geology: impacts of the natural environment on public health, Ed: Selinus, Elsevier, London, UK, ISBN 0-12-636341-2.

Fuge, R. and Johnson, C.C. (1986). The geochemistry of iodine - a review, Environ. Geochem. Health, 8, $31-54$.

Fuge, R. (1989). Iodine in waters: Possible links with endemic goitre, Applied Geochemistry, 4, $203-208$.

Fuge, R. (2005). Chapter 16 Soils and Iodine Deficiency In: Essentials of Medical Geology: impacts of the natural environment on public health, Ed: Selinus, Elsevier, London, UK, ISBN $0-12-636341-2$.

Hem, J. (1992). Study and interpretation of the chemical characteristics of natural water, Water Supply Paper 2254, US Geological Survey, Reston, VA.

Hetzel. B.S. (1989). The story of iodine deficiency: An international challenge in nutrition. New York: Oxford University Press.

http://www.accessmylibrary.com/coms2/summary_0286-32222455_ITM, Rainfall in La Pampa province, Argentina, accessed $21^{\text {st }}$ July 2009.

Ibáñez, J.M., Del Pezzo, E., Bengoa, C., Caselli, A., Badi, G., Almendros, J., 2008, Volcanic tremor and local earthquakes at Copahue volcanic complex, Southern Andes, Argentina, Journal of Volcanology and Geothermal Research, 174 (4), 284 - 294.

ICCIDD (International Council for Control of Iodine Deficiency Disorders) (2003), IDD newsletter, 19 (3).

ICCIDD (International Council for Control of Iodine Deficiency Disorders) (2009), IDD newsletter, 31 (1).

Johnson, C.C., Strutt, M. H., Hmeurras, M., \& Mounir, M. (2002). Iodine in the environment of the High Atlas Mountains, Morocco. British Geological Survey Commissioned Report, $\mathrm{CR} / 02 / 196 \mathrm{~N}$.

Johnson, C.C. (2003a). Database of the iodine content of soils populated with data from published literature. British Geological Survey Commissioned Report, CR/03/004N.

Johnson, C.C. (2003b). The geochemistry of iodine and its application to environmental strategies for reducing risks from iodine deficiency disorders. British Geological Survey Commissioned Report, CR/03/057N, 54pp.

Kebata-Pendias, A. and Pendias, H. (1984). Trace elements in soils and plants. Boca Raton, Florida, USA: CRC Press.

Lewinski, A. (2002). The problem of goitre with particular consideration of goitre resulting from iodine deficiency (I): Classification, diagnostics and treatment, Neuroendocrinology Letters, 23, $351-355$. 
Lim, K.K., Rohana, D.S., Zawiah, A. and Malaimoon, W.M. (2006). An evaluation of the effectiveness of a water iodinator system to supply Malaysia, Tropical Biomedicine, 23, 172 178.

Liu, L-Y., Shi, P-J., Zou, X-Y., Gao, S-Y., Erdon, H., Yan, P., Li, X-Y., Dong, Z-B., Wang, JH., 2003, Short-term dynamics of wind erosion of three newly cultivated grassland soils in Northern China, Geoderma, 115 (1 - 2), 55 - 64.

Maberley, G.F., Eastman, C.J. and Carcoron, J.M. (1981). Effect of iodination of a village water supply on goitre size and thyroid function, Lancet, 2, $1270-1272$.

Morando, J. D., Morrone, A., Beron, E. and Montes de Oca, L. E. (2004). Estudio de las causas de la Endemia de Bocio en ninos de una zona rural de San Juan, con yodurias normales, Revista Argentina de Endocrinologia y Metabolismo, 41 (3), 144 - 151.

O'Reilly, J., Watts, M.J. and Ward, N.I. (2007). Field Based Arsenic Speciation in Argentinian Water Samples: link to arsenic poisoning, Poster, Trace Elements in Diet, Nutrition and Health: Essentiality and Toxicity Conference, $21^{\text {st }}-26^{\text {th }}$ October 2007 , Crete, Greece.

Smedley, P.L., Nicolli, H.B., MacDonald, D.M.J., Barros, A.J. and Tullio, J.O. (2002). Hydrogeochemistry of arsenic and other inorganic constituents in groundwaters from LA Pampa, Argentina, Applied Geochemistry, 17, 3, 259 - 284.

Smedley, P.L., Kinniburgh, D.G., MacDonald, D.M.J., Nicolli, H.B., Barros, A.J., Tullio, J.O., Pearce, J.M. and Alonso, M.S. (2005). Arsenic associations in sediments from the loess aquifer of La Pampa, Argentina, Applied Geochemistry, 20, 5, 989 - 1016.

Stewart, A.G., Carter, L., Parker, A. and Alloway, B.J. (2003). The illusion of environmental iodine deficiency, Environmental Geochemistry and Health, 25, 165 - 170.

Taylor, H., Vickers, B. P., \& Moss-Hayes, V. (2005). Validation of the procedure for the determination of soil pH. British Geological Survey, Internal Report IR/05/080.

Watts, M.J. (2001). Analysis of iodine and selenium in human breast milk and infant formula. $\mathrm{PhD}$ thesis. University of Surrey, Department of Chemistry, Guildford, UK.

Watts, M.J., Button, M, Brewer, T., Jenkins, G.T. and Harrington, C.F. (2008). Quantitative arsenic speciation in two species of earthworms from a former mine site, Journal Environmental Monitoring, 10, $753-759$.

Watts, M.J. \& Mitchell, C J. (2009). A pilot study on iodine in soils of Greater Kabul and Nangahar provinces of Afghanistan, Environmental Geochemistry and Health, DOI 10.1007/s10653-008-9202-9.

WHO. (1993). Arsenic in drinking water, World Health Organisation Factsheet 210, http://www.who.int/medicentre/factshets/fs210/en

WHO. (1994). Indicators for Assessing Iodine Deficiency Disorders and the Control through Salt Iodisation: WHO/NUT/94.6, 1 - 55, World Health Organisation, Geneva. 
WHO. (1996). Trace elements in human nutrition and health, World Health Organisation, Geneva.

WHO. (2004). Iodine status worldwide: World Health Organisation global database on Iodine Deficiency, Geneva.

WHO. (2007a). Assessment of iodine deficiency disorders and monitoring their elimination: a guide for programme managers, $3^{\text {rd }}$ edition, World Health Organisation, Geneva.

WHO. (2007b) World Health Organisation Global database on Iodine Deficiency, http://www.who.int/vmnis/iodine/data/database/countries/arg_idd.pdf

Xiao-E, Y., Wen-Rong, C. and Ying, F. (2007). Improving human micronutrient nutrition through biofortification in the soil-plant system: China as a case study, Environmental Geochemistry and Health, 29, 413 - 428.

Zárate, M.A., J.L. Fasano, 1989, The Plio-Pleistocene record of the central Eastern Pampas, Buenos-Aires Province, Argentina - the Chapadmalal case-study, Palaeogeography, Palaeoclimatology, Palaeoecology, 72, 27 - 52.

Zhao, J., Chen, Z. and Maberly, G. (1998). Iodine rich drinking water of natural origin in China, The Lancet, 352, 2024.

Zimmerman, M. B. (2008). Iodine requirements and the risks and benefits of correcting iodine deficiency in populations, Journal of Trace Elements in Medicine and Biology, 22, 81 - 92.

Tables and Figures

Table 1: Iodine and selenium concentrations for water samples.

\begin{tabular}{|l|l|l|l|l|l|}
\hline Location & Site details & $\begin{array}{l}\text { Iodine } \\
(\mu \mathrm{g} / \mathrm{L})\end{array}$ & $\begin{array}{l}\text { Selenium } \\
(\mu \mathrm{g} / \mathrm{L})\end{array}$ & $\mathrm{pH}$ & $\begin{array}{l}\text { Conductivity } \\
(\mu \mathrm{S} / \mathrm{cm})\end{array}$ \\
\hline San Juan - Surface waters (Except Encon) & \multicolumn{5}{|l|}{} \\
\hline ANG 03 Angualusta & Rio Blanco Above CU 01 & 55 & 1.3 & 8.6 & 1505 \\
\hline ANG 04 Angualusta & Rio Blanco Above CU 01 & 44 & 0.6 & 8.1 & 1350 \\
\hline ANG 05 Angualusta & Rio Blanco Above CU 01 & 52 & 0.9 & 8.6 & 1295 \\
\hline CU 01 Cuesto del Viento & Dam - Rodeo & 60 & 0.9 & 8.8 & na \\
\hline RJ 01 Rio Jachal & Below CU 01 & 29 & 8.2 & 8.8 & 1475 \\
\hline RJ 02 Rio Jachal & Above Rio Caracol input & 62 & 0.9 & 8.8 & 1473 \\
\hline RJ 03 Rio Jachal & Below Rio Caracol input & 63 & 0.8 & 8.8 & 1457 \\
\hline RJ 04 Rio Jachal & Below San Roque & 46 & 0.9 & 8.9 & 1495 \\
\hline RJ 05 Rio Jachal & Niquivil & 58 & 0.9 & 8.8 & 1532 \\
\hline RJ 06 Rio Jachal & Tucunuco & 95 & 1.1 & 8.6 & 1960 \\
\hline
\end{tabular}




\begin{tabular}{|c|c|c|c|c|c|}
\hline AN 01 Agua Negra & Spring water & 48 & 2.1 & 7.8 & 2215 \\
\hline HU 02 Huaco & Rio Huaco - above Huaco & 30 & 3.3 & 8.8 & 2506 \\
\hline HU 03 Huaco & Rio Huaco - centre Huaco & 16 & 2.6 & 8.6 & 2220 \\
\hline HU 04 Huaco & Rio Huaco - below Huaco & 23 & 2.4 & 8.7 & 2215 \\
\hline EN 08 Encon & Garden, centre of village - tap & 28 & $<0.5$ & 9.6 & 1248 \\
\hline EN 09 Encon & Garden $300 \mathrm{~m}$ from centre - well & 27 & $<0.5$ & 9.7 & 1221 \\
\hline EN 10b Encon & \begin{tabular}{l|l} 
Centre - well &
\end{tabular} & 30 & 0.7 & 9.6 & 1352 \\
\hline EN 10c Encon & Centre - storage before filtration & 16 & $<0.5$ & 9.6 & 1254 \\
\hline EN 10a Encon & Centre - filtered & 17 & $<0.5$ & 9.2 & 1101 \\
\hline EN 11 Encon - 10 km S.East & Borehole $-300 \mathrm{~m}$ deep & 16 & $<0.5$ & 9.7 & 1390 \\
\hline EN 12 Encon - village garage & Borehole $-15 \mathrm{~m}$ deep & 29 & $<0.5$ & 9.7 & 1046 \\
\hline \multicolumn{6}{|l|}{ La Pampa - Groundwaters } \\
\hline EC 51 & Campo Vidile - well 7 m deep & 64 & $<0.5$ & 8.6 & 767 \\
\hline EC 52a & Campo Marchisio well & 104 & 14.8 & 8.3 & $>3999$ \\
\hline EC 52c & Campo Marchisio well & 112 & 14.5 & 8.2 & $>3999$ \\
\hline EC 53 & Campo Nelso well & 88 & 2.6 & 9.9 & $>3999$ \\
\hline EC 54 & Campo Nelso well & 102 & 3.1 & 9.7 & $>3999$ \\
\hline EC 55 & Campo Macagno well & 108 & 5.4 & 8.8 & $>3999$ \\
\hline EC 56a & San Juan Bautista well & 212 & 4.4 & 8.7 & 2514 \\
\hline EC 56b & San Juan Bautista house & 219 & 1.6 & 8.7 & 2491 \\
\hline EC 56c & San Juan Bautista well & 223 & 5.5 & 8.7 & 2495 \\
\hline EC 57 & Campo Coralis well & 316 & 6.2 & 8.7 & 2610 \\
\hline EC 58 & Campo Perez well & 110 & 21.3 & 8.0 & $>3999$ \\
\hline EC 59a Treatment works & Raw Input & 395 & 6.2 & 8.2 & 3120 \\
\hline EC 59c Treatment works & Treated after reverse osmosis & 148 & 4.3 & 8.2 & 3254 \\
\hline EC 60 & Town Borehole & 262 & 8.2 & 8.5 & 3494 \\
\hline EC 61a & Town Borehole & 148 & 5.9 & 8.6 & 3478 \\
\hline EC 8 S2 Campo E1 Laurel & Borehole & 219 & 9.9 & 8.4 & $>3999$ \\
\hline LU 40 & Borehole: $25 \mathrm{~m}$ deep & 97 & 5.5 & 8.6 & 2620 \\
\hline LU 41 & Borehole: $25 \mathrm{~m}$ deep & 63 & 5.3 & 8.7 & 2640 \\
\hline LU 42 & Borehole: $25 \mathrm{~m}$ deep & 79 & 0.8 & 8.6 & 1120 \\
\hline LU 39a Treatment works & Raw water & 52 & 2.9 & 8.6 & 2202 \\
\hline LU 39b Treatment works & Raw water mixed wells & 61 & 4.0 & 8.7 & 2155 \\
\hline LU 39c Treatment works & Addition of Chloride & 60 & 3.7 & 8.6 & 2145 \\
\hline LU 39d Treatment works & Residual waste- reverse osmosis & 87 & 4.7 & 8.5 & 3655 \\
\hline LU 39e Treatment works & Water after reverse osmosis & 1.4 & $<0.5$ & 8.5 & 9 \\
\hline LU 39f Treatment works & Mineralised with salts & 7 & $<0.5$ & 8.5 & 11 \\
\hline LU 39g Treatment works & Drinking water & 1.2 & $<0.5$ & 8.7 & 50 \\
\hline
\end{tabular}

Table 2: Iodine and selenium concentrations for soils.

\begin{tabular}{|c|c|c|c|c|c|c|c|}
\hline Location & Site details & $\begin{array}{l}\text { Iodine } \\
(\mathrm{mg} / \mathrm{kg})\end{array}$ & $\begin{array}{r}\text { Selenium } \\
(\mathrm{mg} / \mathrm{kg})\end{array}$ & $\mathrm{pH}$ & $\begin{array}{l}\text { LOI } \\
(\%)\end{array}$ & $\begin{array}{l}\text { Mobile Iodine } \\
(\mathrm{mg} / \mathrm{kg})\end{array}$ & $\begin{array}{l}\text { Mobile } \\
\text { Iodine (\%) }\end{array}$ \\
\hline \multicolumn{8}{|l|}{ San Juan } \\
\hline ANG 03 Angualusta & Above Dam- CU01 & 0.30 & 0.30 & 8.0 & 1.1 & 0.07 & 25 \\
\hline CU 01 Cuesto del Viento & Dam - Rodeo & 0.26 & 0.46 & 7.8 & 0.1 & 0.05 & 18 \\
\hline RJ 02 Rio Jachal & Above Rio Caralaco & 1.63 & 0.52 & 7.7 & 1.6 & 0.22 & 13 \\
\hline RJ 03 Rio Jachal & Below Rio Caracol input & 0.39 & 0.40 & 8.4 & 1.3 & 0.17 & 42 \\
\hline RJ 04 Rio Jachal & Below San Roque & 0.74 & 0.27 & 7.8 & 0.9 & 0.02 & 2 \\
\hline RJ 05 Rio Jachal & Niquivil & 0.29 & 0.25 & 7.6 & 0.5 & 0.07 & 23 \\
\hline RJ 06 Rio Jachal & Tucunuco & 0.52 & 0.33 & 7.8 & 0.7 & 0.08 & 15 \\
\hline AN 01 Agua Negra & $2 \mathrm{~m}$ from stream & 10.47 & 0.29 & 7.3 & 1.1 & 0.93 & 9 \\
\hline HU 02 Huaco near Rio Huaco & Above Huaco $-10 \mathrm{~m}$ on bank & 4.76 & 0.65 & 7.8 & 1.6 & 0.74 & 16 \\
\hline HU 03 Huaco near Rio Huaco & Centre Huaco $-10 \mathrm{~m}$ on bank & k 0.13 & 0.25 & 8.0 & 0.5 & 0.05 & 35 \\
\hline HU 04 Huaco near Rio Huaco & Below Huaco $-10 \mathrm{~m}$ on bank & 0.12 & 0.18 & 7.9 & 1.0 & 0.03 & 23 \\
\hline EN 08 Encon & Garden, centre of village & 4.20 & 0.21 & 6.7 & 2.3 & 0.19 & 4 \\
\hline EN 09 Encon & Garden, $300 \mathrm{~m}$ from centre & 0.05 & 0.12 & 8.8 & 0.9 & 0.01 & 15 \\
\hline
\end{tabular}




\begin{tabular}{|l|l|l|l|l|l|l|l|}
\hline \multicolumn{2}{|l|}{ La Pampa } \\
\hline EC1 S1 Campo Don Santiago & Soil near water tank & 3.65 & 0.31 & 6.5 & 3.3 & 0.09 \\
\hline EC1 S2 Campo Don Santiago & Garden soil & 2.18 & 0.23 & 6.5 & 7.7 & 0.05 \\
\hline EC2 S1 San Juan Bautista & Garden soil & 1.21 & 0.21 & 7.1 & 2.1 & 0.06 \\
\hline EC2 S2 San Juan Bautista & Garden soil & 1.97 & 0.26 & 6.9 & 2.6 & 0.14 \\
\hline EC2 S4 San Juan Bautista & Garden soil & 1.40 & 0.14 & 6.8 & 3.7 & 0.13 \\
\hline EC2 S5 San Juan Bautista & Soil near water tank & 4.62 & 0.20 & 9.1 & 2.4 & 0.82 \\
\hline EC2 S6 San Juan Bautista & Soil beneath garden tap & 1.79 & 0.20 & 7.9 & 3.2 & 0.29 \\
\hline EC2 S7 San Juan Bautista & Soil from field & 2.53 & 0.23 & 6.9 & 3.3 & 0.08 \\
\hline EC4 S1 Eduardo Castex & From waterworks & 2.27 & 0.19 & 7.1 & 3.7 & 0.08 \\
\hline EC4 S2 Eduardo Castex & Urban garden & 2.94 & 0.24 & 7.1 & 3.8 & 0.05 \\
\hline EC6 S1 Campo Brizio & Soil next to well & 2.52 & 0.26 & 6.6 & 2.8 & 0.08 \\
\hline EC6 S2 Campo Brizio & Soil from field & 1.91 & 0.26 & 6.9 & 2.7 & 0.04 \\
\hline EC7 S1 Campo Gomez & Vegetable plot & 3.34 & 0.26 & 7.5 & 5.9 & 0.04 \\
\hline EC7 S2 Campo Gomez & Soil near water tank & 20.93 & 0.71 & 8.7 & 5.7 & 0.94 \\
\hline EC8 S1 Campo El Laurel & Garden soil & 2.12 & 0.29 & 6.7 & 2.9 & 0.15 \\
\hline EC8 S2 Campo El Laurel & Soil next to well & 4.04 & 0.21 & 7.5 & 4.5 & 0.21 \\
\hline
\end{tabular}
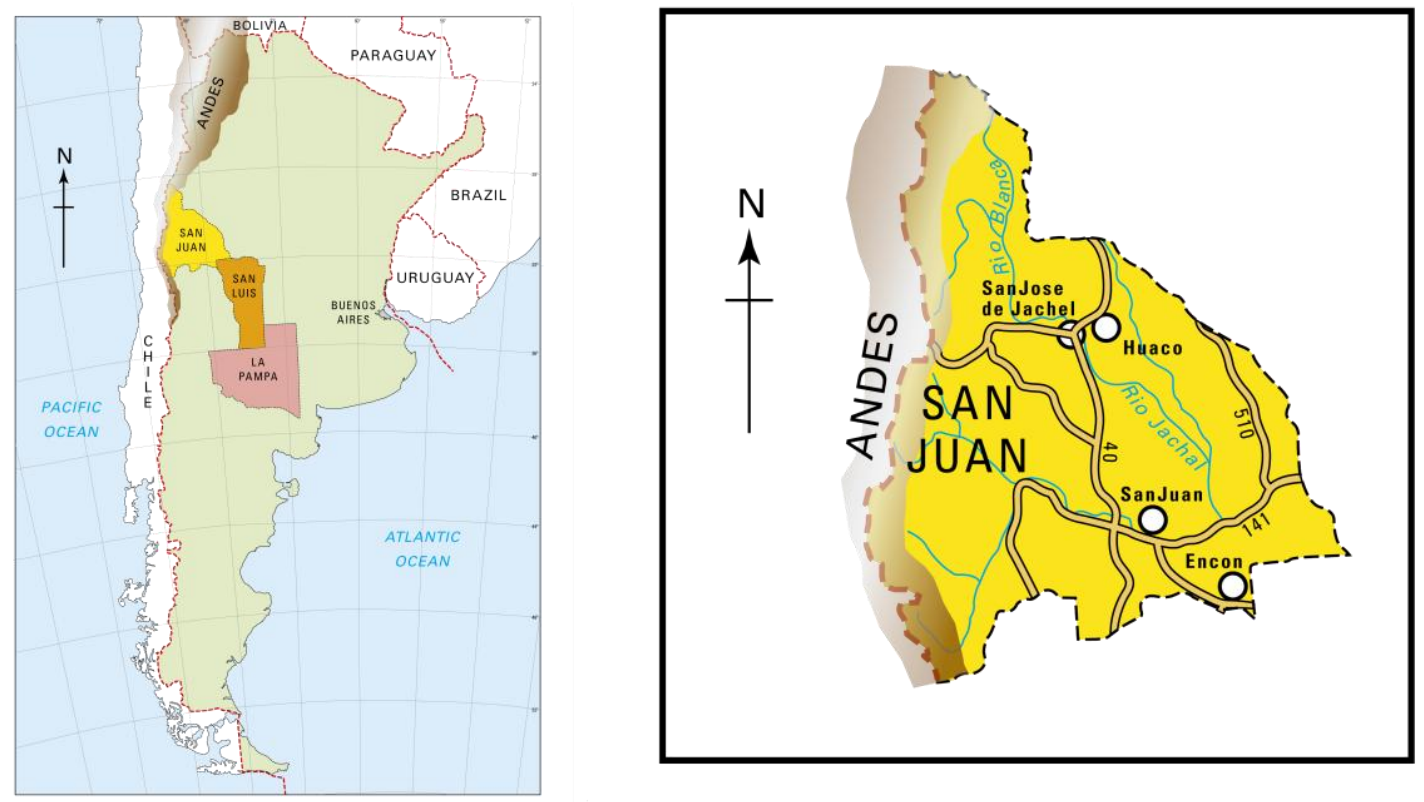


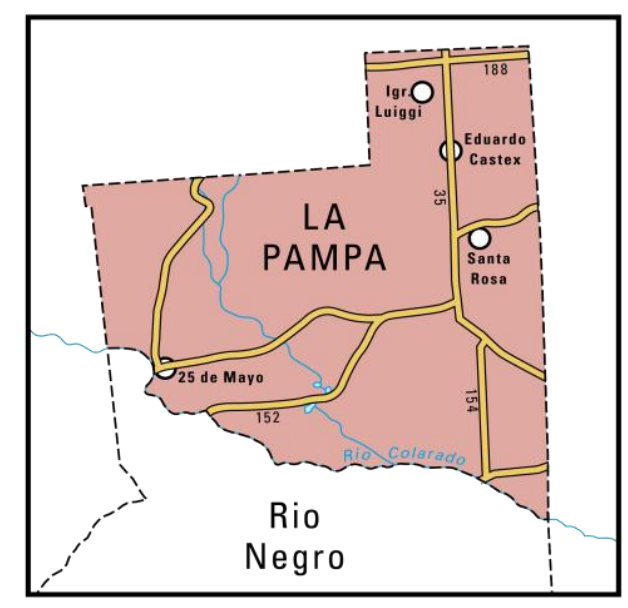

Figure 1: (a) Argentina and the (b) San Juan and (c) La Pampa provinces, prepared courtesy of Mr Paul Lappage, British Geological Survey, 2008.

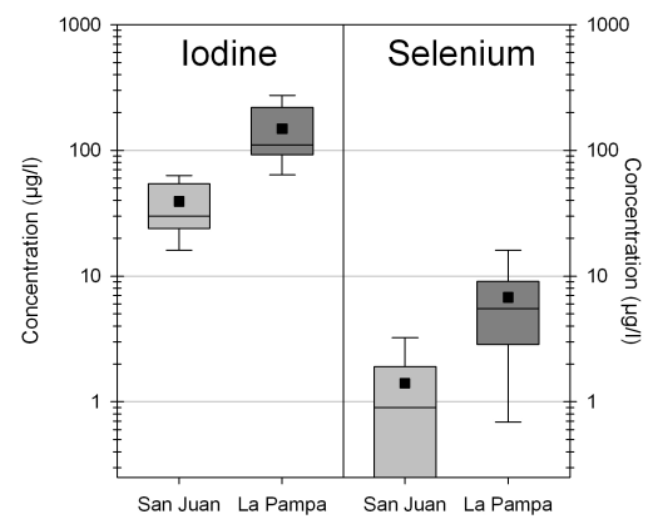

Figure 2: Summary of iodine and selenium concentrations in waters.

Box-and-whisker plots show the inter-quartile range as the box, with the median as a horizontal line in the box and the mean as a square symbol. The whiskers locate the $5^{\text {th }}$ and $95^{\text {th }}$ percentiles of the data.

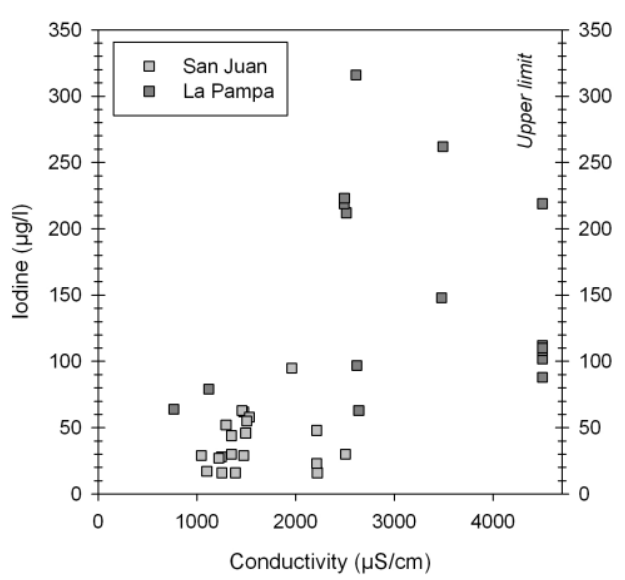

Figure 3: Relationship between conductivity and iodine in waters. 


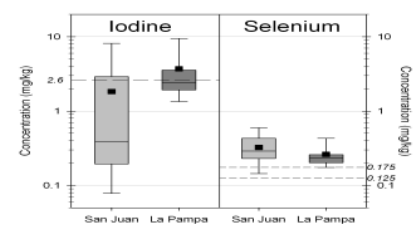

Figure 4: Summary of iodine and selenium concentrations in soils. see Figure 2 for description of the box-and-whisker plot symbols.

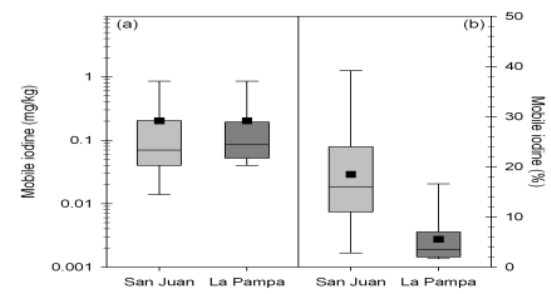

Figure 5: Mobile soil-iodine / -selenium concentrations compared to percentage values. see Figure 2 for description of the box-and-whisker plot symbols.

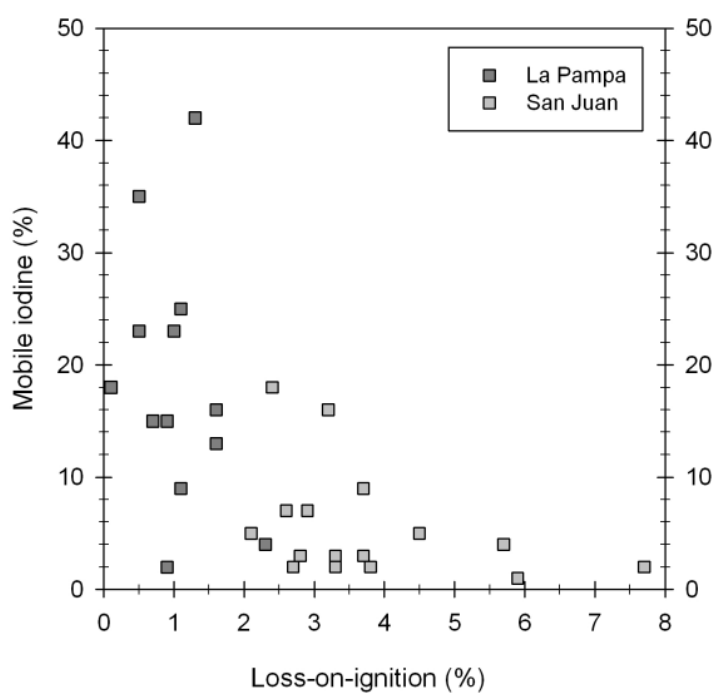

Figure 6: Relationship between organic content of soils and (\%) mobile soil-iodine. 